Vaneasa Online Journal

$4.2 \mid 2016$

Imagination/Ineffability

\title{
The Lives of Other Citizens
}

\section{Andrew Irving}

\section{OpenEdition}

\section{Journals}

Electronic version

URL: http://journals.openedition.org/anthrovision/2390

DOI: 10.4000/anthrovision.2390

ISSN: 2198-6754

\section{Publisher}

VANEASA - Visual Anthropology Network of European Association of Social Anthropologists

\section{Electronic reference}

Andrew Irving, «The Lives of Other Citizens », Anthrovision [Online], 4.2 | 2016, Online since 31

December 2016, connection on 19 April 2019. URL : http://journals.openedition.org/anthrovision/2390 ; DOI : 10.4000/anthrovision.2390

This text was automatically generated on 19 April 2019.

(c) Anthrovision 


\title{
The Lives of Other Citizens
}

\author{
Andrew Irving
}

\section{Taking a Journey into New York's Thoughtscape}

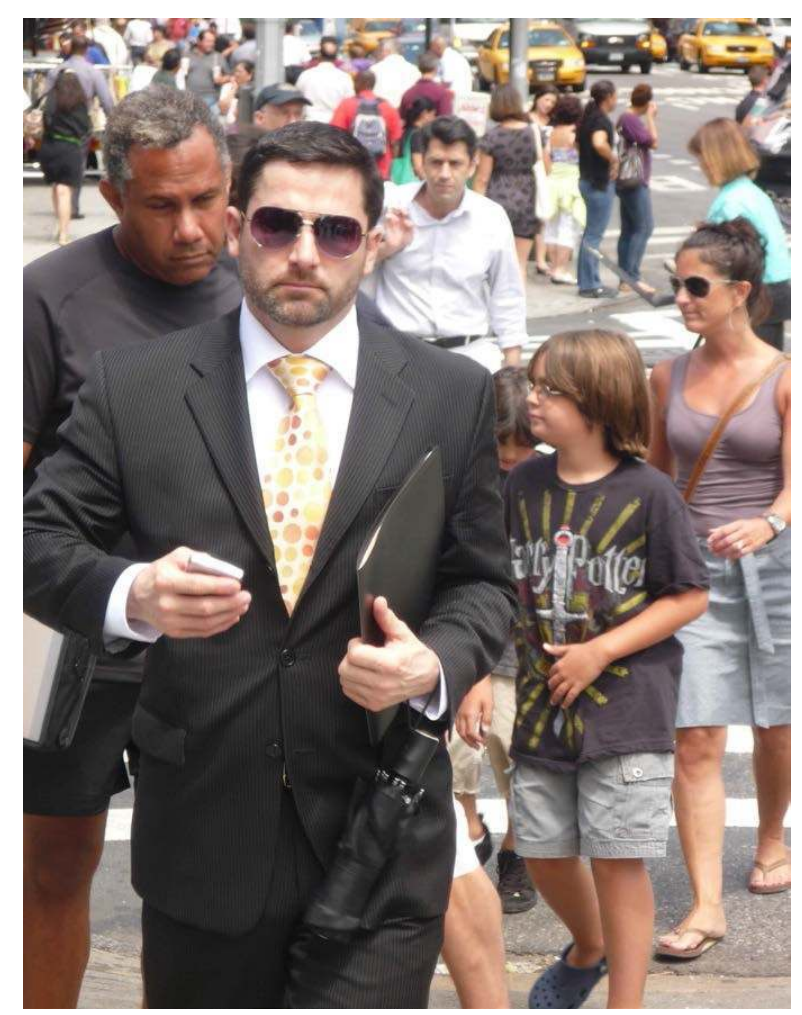

All Photos by Andrew Irving

1 I would like to begin with a question about the above photograph of New York street life that I took while waiting on a street corner for a friend. Although the question is easy to ask, it is extremely difficult to answer, for it not only places us beyond anthropological knowledge and understanding but beyond the limits of science itself. 
As with any crowded street, the people seen in the photographs dispersed throughout this text are likely to be engaged with a wide a range of internally expressed thoughts and emotions. One person might be debating what to have for lunch or silently singing the lyrics of a pop song, while others are reminiscing about their childhood, fretting about money or fantasising about a work colleague. Out of the thousands and thousands of thoughts simultaneously being expressed inside people's heads on the streets of New York in any given moment, it is likely many will concern people's everyday social life, relations and activities, alongside shared themes, topics and interests, such as the weather, current events, news stories and so forth. Other people's inner dialogues might be directly responding to the life of the street, including the observation and interpretation of the people, buildings, adverts and shops that surround them. Or perhaps more accurately, given the multifaceted and stream-like character of inner dialogue, with its rapid shifts in subject matter and characteristic patterns of free association, persons can be found continually switching between different topics and registers of interest and attention as they move around the city. On the one hand, this reveals the shared social, cultural and historical basis of people's internalised modes of expression-which provides inner expression with some form of collective content, shape and structure-but on the other hand it simultaneously discloses a person's specific interests, idiosyncratic worldview and ongoing existential concerns.

5 As documented in Ethnography, Art and Death (Irving 2007), a person might be walking around a city looking for a place to commit suicide or alternatively might be contemplating the radical uncertainty of being while sitting in a café or walking down a crowded street having recently been diagnosed with a serious or terminal illness (see Irving 2010, 2011). In such cases, the person remains a social being and is required to act in a communal public space, but their thoughts and concerns are not necessarily externalised or apparent to the wider world. From negotiating illness or thinking about suicide to deciding what shoes to buy or daydreaming about being a superhero: a city's streets, cafes, parks, squares and trains contain everything that life has to offer-from the mundane and commonplace to the tragic and the taboo-only we do not have access to it. Together this vast diversity and multiplicity of thought, freely ranging across time, space and subject matter, combines to produce the collective underlying thoughtscape of contemporary urban life. 

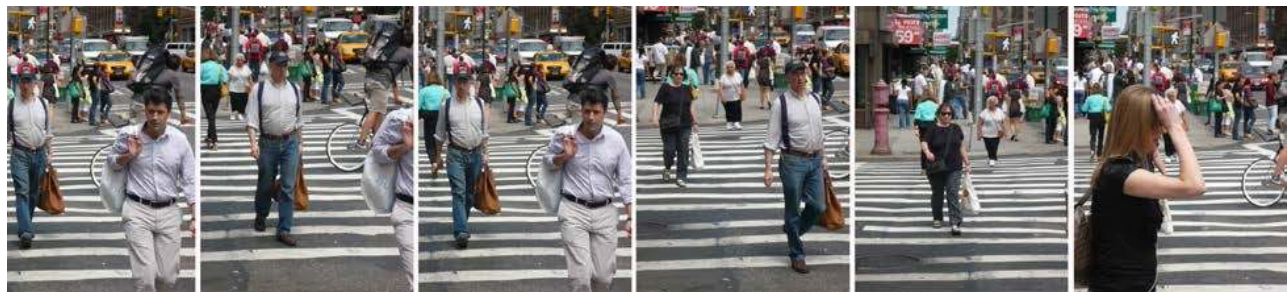

It is a thoughtscape that consists of the continuous streams of inner dialogue, memory and imagination that comprise people's everyday lives and practices and mediate their engagement with their social and material surroundings. Although we ourselves are part of it, we are mostly unaware of the thoughtscape that unfolds around us. For while human beings are highly skilled at looking at, reading and interpreting other persons, there is no direct access to other people's thoughts and it is far from straightforward to discern the inner dialogues of the people we see in public places by their external appearance alone. Nowhere is this made more apparent than in Eric Steel's documentary about the Golden Gate Bridge, The Bridge (2006) for which Steel and his twelve-person film crew turned up every morning for an entire year to document a year in the life of the iconic bridge. The film captures 23 of the 24 known suicides that occurred on the bridge that year, alongside numerous other persons who were talked down or otherwise dissuaded from jumping. The film crew themselves managed to intervene on six occasions to prevent people committing suicide but it was noticeable that there was often little indication about who was contemplating ending their life from people's behaviours and appearances. As such, the very first suicide captured by the film crew's telephoto lenses was not acting in the manner that the camera operators expected. He was not crying, looking agitated or anguished or showing any extraneous signs of distress but rather was jogging and talking and laughing on his cell phone. Then all of a sudden he climbed the barrier, made the sign of the crucifix and leapt to his death.

Without the ability for internalised forms of expression that exist beneath the surface of people's public activities and utterances, many aspects of social life and interaction would be severely compromised, including people's abilities to plan, reflect upon and understand their actions in the world or to make interpretations about other persons and situations. It would mean that social relations, parenting, board games, negotiating, bartering and simple acts of secrecy, lying and deception would be rendered impossible, as persons would be unable to simultaneously hold private intentions, information and motives in their mind that differ from those that are publicly articulated.

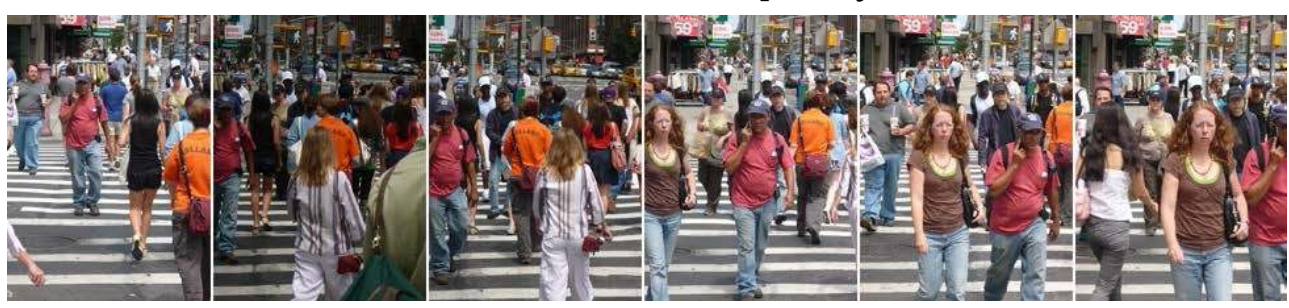

The critical role and significance of inner speech and expression to human experienceor what William James's described as 'the mind's conversations with itself' (James 1890: 239)-is widely recognised in brain science, neurology and linguistics (Ward 2006, Hurlburt 2009, Fernyhough 2013) as outlined by Peter Carruthers in the journal Behavioural and Brain

Sciences: 
10 'Although proportions vary, many people seem to spend a good deal of their waking activity engaged in "inner-speech," with imaged natural language sentences occupying a significant proportion of the stream of their conscious mentality' (Carruthers 2002: 657).

11 Inner expression is a shared phylogenetic capacity that is fundamental to a wide range of human experiences-from routine and mundane practices to highly charged events and extraordinary moments of existential crisis-and is a key means through which people negotiate social life and social relations. Simply put, without inner expression there would be no self-understanding or social existence, at least not in a form we would recognise. However, despite the centrality of inner expression to many, if not most, forms of social activity, it is a subject that is largely uncharted across the social sciences and is rarely, if ever, the subject of ethnographic research or anthropological monographs. For the most part people's inner expressions are seen as irrelevant or intangible-rather than as empirical phenomena that are directly constitutive of people's lived experiences and actions-meaning that anthropology, the quintessential study of humanity, risks telling only half the story of human life.

12 Following Crapanzano (2004), I argue the problem is less to do with social- scientific measures and methods per se but with the narrow historical and disciplinary definitions of what constitutes 'reality' and what is considered empirically admissible or worthy of anthropological and social scientific investigation. An anthropological approach to inner expression in social life needs to be grounded in empirical and ethnographic data across a range of contexts, practices and experiences rather than addressed or argued about at remote levels of theoretical abstraction and speculation. This presents a number of significant epistemological and ethnographic challenges, first, because there is no independent, objective access to another person's consciousness or experience: more colloquially put as there being no way of looking inside someone else's head; second, because understanding the content and character of inner dialogue and expression is primarily a practical, ethnographic and methodological problem, to be researched in the field; and third, because conventional social-scientific approaches are often too static to understand or represent the transient, stream-like and ever-changing character of people's interior expressions and experiences as they emerge in situ from moment to moment.

In response, this article combines the idea of 'walking fieldwork', early modernist literature and the use of digital media to explore and offer ethnographic insights into the complex layers of inner expression, imagery and emotion that constitute New York's thoughtscape. Walking Fieldwork ${ }^{1}$ is a technique, inspired by writers such as Robert Walser, alongside film-makers such as Jean Cocteau and Jean Rouch, that I originally developed to try to understand the experience of living with illnesses, such as cancer and HIV/AIDS, and the effect of illness on the moving body in relation to the challenge of carrying out daily routines, roles and practices when living with an unstable body (see Irving 2005, 2007). Walser was among the very first writers to explicitly suggest the necessity of walking to thought, consciousness and writing and his work influenced Kafka, Benjamin and Sebald's own meditations about walking. Walser was a compulsive walker who often took extended forays throughout the night into unfamiliar parts of the city. His short story, The Walk (1917) recounts an attempt by the police to arrest him for unpaid taxes. Walser pleads for clemency as an impoverished pen-pusher and homme de letters with only a dubious income, to which the inspector declares that he cannot possibly be a writer by exclaiming: "But you're always to be seen out for a walk!'. Walser replies: 
Walk", was my answer, "I definitely must, to invigorate myself and to maintain contact with the living world, without perceiving which I could not write the half of one more single word, or produce the tiniest poem in verse or prose. Without walking, I would be dead, and my profession, which I love passionately, would be destroyed." Also, without walking and gathering reports, I would not be able to render one single further report, or the tiniest of essays, let alone a real long story. Without walking, I would not be able to make any observations or studies at all. On a lovely and far-wandering walk a thousand usable and useful thoughts occur to me. Shut in at home, I would miserably decay and dry up."' (Walser 1992).

Countless writers have subsequently described the close relationship between thinking and walking, while the idea of explicitly combining walking, performance and photography in urban space stretches at least as far back as Picasso's walking tour of Paris as staged and photographed by Jean Cocteau during the First World War on 12 August 1916. It was further developed in Rouch and Morin's film Chronicle of a Summer in the summer of 1960 where the new technology of synchronous sound opened up new creative possibilities for combining film, walking and narration. Rouch and Morin used a combination of participatory film practice, interviewing, life history and performance in order to reveal aspects of their subjects' lives that would otherwise remain dormant (see Irving 2007, Henley 2009).

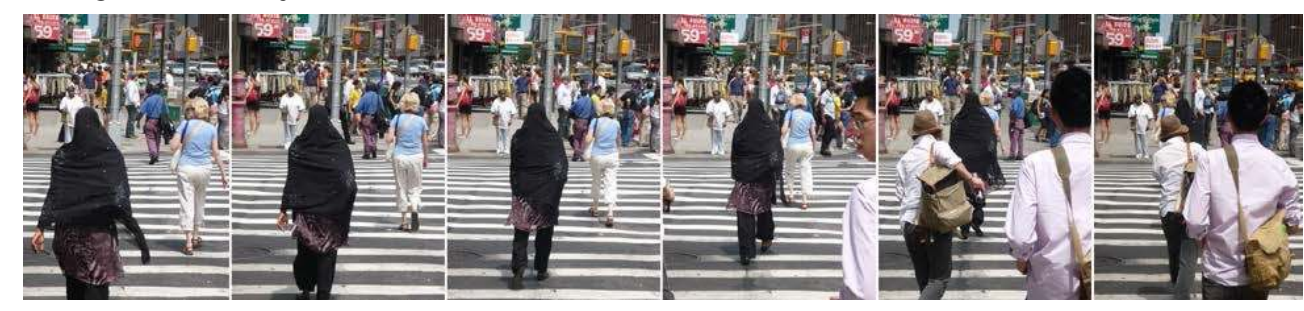

Building on this, the aim of the current project is to engage with the thinking, moving body, as it interacts with different parts of the city, in an attempt to consider how urban experience is mediated by streams of inner dialogue, memory and imagination that emerge in situ and are often rooted in a person's current existential situation and concerns.

17 Accordingly, the following video and sound recordings derive from an experimental ethnographic research project, New York Stories for which I recorded more than a hundred interior dialogues of random strangers encountered as they moved around the city. The first stage involved dividing New York into different zones of thought, namely streets, bridges, cafes, squares, in order to recognise the potential for different kinds of urban space to generate different modes of cognition and experience that are played out in public but are not necessarily externalised. The method was very simple. I approached random persons I encountered in these areas and asked then what they were thinking about in the moment immediately before I approached them. I then explained the project and invited them to wear a small microphone and speak out loud the stream of their thoughts as they continued with activities. I found it surprising not just the level of interest in the nature of the project but the amount of people, from all walks of life, who said yes.

The recordings can only ever offer the merest of glimpses into those realms of inner expression and experience that can be articulated and approximated in language within a public and highly performative encounter, and so cannot claim to provide anything more than a partial and passing instance of the complexity and diversity of people's inner 
lifeworlds. People's inner lifeworlds simultaneously encompass many different modes of thinking and being-ranging from vague, barely graspable and transitory experiences that exist on the periphery of our consciousness and bodily awareness-to more purposeful and defined forms that enable us to establish a continuous sense of self. Certain aspects remain inchoate and beyond the reach of language, while others coalesce and become articulated into stable symbolic forms for particular purposes, including intentional, descriptive, analytical and communicative purposes, thereby forming a basis for narrative expression to oneself and/or others. As such, by focusing on interior dialogue, as one particular mode of inner expression among others, the article attempts to position itself as a methodological contribution to the anthropology of interiority by exploring how complex trajectories of thinking and being are played out in public spaces but are not necessarily externalised.

We are obviously not hearing people's thoughts in themselves but their verbal articulation in a public context, and as such they are not only subject to varying levels of personal disclosure, self-censorship and the act of recording but also by the limits of linguistic expression. Importantly, not all thought processes take place in language and thought routinely incorporates various non-linguistic, imagistic, and non-symbolic modes of thinking that operate close to the threshold or beyond the realm of language. In other words, the inner dialogues that accompany this article are best regarded as performative instantiations of the type of inner voice and linguistic representation through which people self-consciously understand, negotiate and re-imagine their surroundings, themselves and others. It is a process that involves a rendering of perception and experience into speech in a way that can be likened to the kinds of ekphrastic description used to describe art. Coming from the Greek Ek (out) and phrasis (to speak), ekphrasis, relies upon the translation of one form into another, for example when offering a verbal description of a visual phenomenon, such as when describing a work of art and having to translate it into words to someone who has never seen it (Irving 2013).

The reader is now invited to watch some short video excerpts online, or they can download sounds clips onto their phone or MP3 player and walk around their own neighbourhood with someone else's thoughts in their heads: or sit in a café or cross a bridge or ride a train. Each clip contains 3 inner dialogues of about 3 or 4 minutes duration but are taken from the full-length recordings that range from 15 minutes to 1.5 hours. They are also presented without background information, akin to the way that people mostly encounter each other in public spaces as strangers and to provide an experiential affinity with the way persons dwelling alongside each other in cities are often unaware of the expressive inner lives of the people that surround them. 
New York Stories (sound documents)

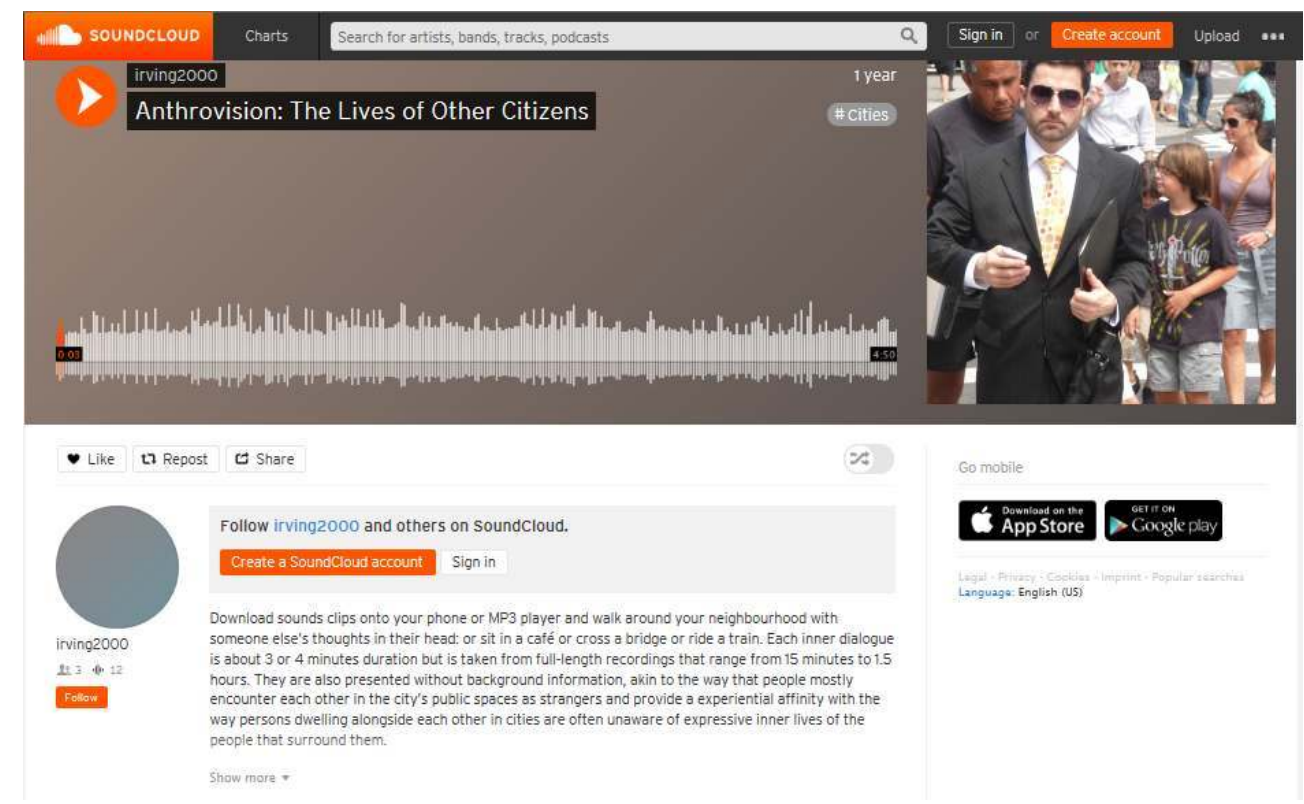

Load "New York Stories" sound files onto MP3 player or smart phone: https://soundcloud.com/ irving2000/sets/anthrovision-the-lives-of-other-citizens

Recorded by Andrew Irving

Or watch the video excerpts here:

This media file cannot be displayed. Please refer to the online document http:// journals.openedition.org/anthrovision/2390

Video link: https://vimeo.com/64922792

This media file cannot be displayed. Please refer to the online document http:// journals.openedition.org/anthrovision/2390

Video link: https://vimeo.com/64922800

This media file cannot be displayed. Please refer to the online document http:// journals.openedition.org/anthrovision/2390

Video link: $\underline{\text { https://vimeo.com/64922797 }}$

This media file cannot be displayed. Please refer to the online document http:// journals.openedition.org/anthrovision/2390

Video link: https://vimeo.com/64922801 


\section{Ekphrastic Adventures}

26

Meredith debating the tragic irony of thinking her friend's cat was dying and then finding out her friend had cancer; Thomas thinking about Depression-era Detroit, the soup kitchen and the future of the automobile industry; Jim crossing the ocean and many years to remember a night in 1964 at a cinema in Birmingham, England; Sara imagining herself flying above the water and thinking about the personality of the man who designed the bridge she had waited so long to walk on; Tony contemplating what might happen if a close friend has a baby; Keith sitting outside a café fictionalising and narrating the people around him, Terrence sitting outside the same café being made aware of his black skin when a cop looks at him; Laura waiting for her partner and questioning their relationship and so on. It soon becomes apparent that there are as many ways of thinking as there are of speaking. By listening in to the thoughts of strangers in their daily life as they walk around the city and across bridges or sit in squares and cafés, we are offered a glimpse into the different modes of inner dialogue, imagery and memory that constitute the thoughtscape of the city.

To be in the city is to be located at all times within a meshwork of intersecting thoughts and to be part of a continuous and collective interaction with the sights, sounds, tastes, smells and textures which impress themselves onto the collective nervous system. As one moves around and engages with the city, the eye and ear pick up far more information than can be effectively described in words as part of an internal or external narrative. Moreover, whereas our being-in-the-world is experienced as a complex assemblage of perception and sensation - in which the simultaneous co-presence of emotion, mood, and memory mix with movement to constitute our embodied lived experience of the moment - language is largely linear in its structure and expression and unfolds over time. As such what is experienced simultaneously across different perceptual and sensory modalities, including those of sight, sound, smell, and so forth, can only be expressed verbally in a sequential, linear fashion. We need to recognise, therefore, that the fragments of spoken thought that accompany this paper, like all speech, involves a distortion, reduction, and linearisation of the simultaneity of people's lived and sensory experience (many aspects of which are impossible to articulate to oneself or others). When understood as part of a wider range of corporeal and sensory effects that constitute someone's lived experience, it becomes apparent that what is present to and is constitutive of being in any particular moment far exceeds that which can be articulated through linear forms of speech or text.

This reinforces how lived experience is a whole-body phenomena that intertwines inner expression with nerve-based activity and that interiority does not imply a bounded person or sterile dichotomy of inner/outer. People's thinking and being are not contained by the boundaries of the physical body but are an emergent property of the interaction between body and world in which both the perceiving organism and the world are in constant process. This is not a new idea and recalls Marx's (1988) discussion of the effects of labour and capitalism upon the sensory body in his Economic and Philosophical Manuscripts of 1844, as well Bateson's ecological anthropology (1972) in which persons are seen as constituted via a complex set of interactions with the environment. This illustrates how people's inner expressions are neither bounded nor fixed but are continuously generated within the interaction between person and world, 
and thereby challenging any assumed opposition of inner/outer in which interiority is seen as directed 'inwards' and sociality 'outwards'.

The recordings make apparent that New York's streets, cafes, bridges and squares are complex sites of experience and expression that at times can be highly dramatic or theatrical and at other times predictable or routine, except we cannot see or hear the myriad inner dialogues that are going on underneath the surfaces of people's public activity. Meredith's inner dialogue, for example, stretches from the routine to great emotional density over a few short steps as she begins by looking for a Staples stationary store to buy CD covers, then shortly after is dwelling on a friend's cancer diagnosis that she learnt about the previous night. Meanwhile, she looks over the road and notices a cafe she likes to watch people in. The associative chain of thought constantly moves between different modalities.

By contrast, Thomas is concerned with people's prospects in the current social and economic climate and his thoughts are organised as a sustained social analysis and argument about the position of working people and the historical migration of black workers from the agricultural south to the industrial north. His inner dialogue reveals much about the historical constitution of thought and consciousness. Tellingly, out of the 100 or more inner dialogues I recorded, a significant proportion were explicitly linked to global economic uncertainty and/or national security issues that have over-shadowed many people's social lives since $9 / 11$ and the banking crisis. If the project was undertaken in the relative economic and political stability prior to $9 / 11$, the collective and social constitution of thought would have had a markedly different character, thus highlighting how inner dialogues are historical and articulated in a particular social, political and economic moment.

31 Tony and Laura's thoughts, as with many other inner dialogues I recorded, concerns the centrality of personal relations to everyday life. Tony is a writer and video artist who is walking to his house, his thoughts emerging in staccato bursts: as he walks quicker and his blood circulates faster he begins to get more argumentative with himself as he negotiates a significant life event and keeps returning to the same words suck it up or let it go. Laura, meanwhile waits anxiously in a café for a message from her partner, wondering where he is and imagining a range of different scenarios from spending the night with a one night stand to a bus crash.

Jim, a retired doctor from Manchester, England, habitually spends afternoons roaming New York exploring the ambience and architecture of different Manhattan neighbourhoods: a passing car playing The Beatles' "Hard Day's Night" transports him from the immediacy of Manhattan to an evening in 1964 in Birmingham, England, and begins a trajectory of thought concerning a friend he has not seen for more than forty years.

Venturing onto Manhattan Bridge for the first time in many decades, Joyce looks down onto the buildings in her neighbourhood that she normally looks up at. Her memories of crossing the bridge with her father as a young girl are intertwined with the vertiginous sensation of being high above the ground and the sheer noise and vibration of the trains going by. For Joyce this generates a unique experience of the bridge that combines nervous uncertainty, a meditation on her childhood and more recent past, and a reassuring recourse to religious faith. 
In explicit contrast to Joyce, when Yuri walks on the bridge, he experiences "a calming sense" that is not always readily available or easy to achieve in other areas of his daily life. Conceived as a succession of trials and tests, day-to-day life continues to be overshadowed by the suicide of his former partner. Yuri describes how he is able to establish a sense of calm and freedom while walking across the Brooklyn Bridge that is often denied to him elsewhere. This not only demarcates a key difference between his and Joyce's experience of being on a bridge but emphasises how each bridge has a different character that helps establish someone's lived experience of the moment. Both Yuri and Joyce's thoughts turn to the suicide of others, however, while for Yuri the Brooklyn Bridge affords a sense of calmness that is made manifest in his body, Joyce experiences the Manhattan Bridge as a site of nervous anxiety.

In Sara's inner dialogue, her words describe a kind of magic that is contained in the bridge itself, something miraculous and something magnetic that is "not seen with regular eyes" or "easy to express" but which generates feelings that combine flying on water and something like "wishes." Sara had travelled all the way from Israel to walk across the very same bridge whose photograph adorns her wall at home. At times her words resort to metaphor in an attempt to overcome the difficulty in expressing how she feels and describes her experience as like flying on water. However, she is not always using metaphor and when she declares that there must be something in the bridge; this is a statement of fact and not similitude.

fifferent modalities through which each of these citizens encounters the city not only gives weight to Heidegger's argument that people's interactions with, and understandings of, the world are never free floating insofar as they are always disclosed through a specific state of mind (1962), but also William James's notion that while experience and consciousness are fluid properties generated through action they are also partially constituted by various modes of thinking and being that repeat or persist over time so as to create an experience of a world seemingly "shot through with regularities" and "essentially bound up with the way in which one moment in our experience may lead us towards other moments" (James 2000:90).

Importantly the fragments of inner dialogues presented here demonstrate how human beings are never fully in control of their own thoughts. Sometimes an event, memory or phrase repetitively comes into consciousness unwanted and unbidden. The person may desperately want to be thinking about something else but the subject or memory keeps coming back. A bad day at work that one keeps trying to forget, a hurtful comment that keeps getting replayed, a sexual obsession, a friend being diagnosed with cancer, a song's refrain repeating, fearing for one's job or someone having a baby: we may want to change the subject but find ourselves, like Tony or Yuri or Meredith, repeatedly coming back to the same topic, thinking about something that we only have partial agency over. At the same time, the environment impinges on the content and character of thought, as is made apparent in Jim's inner dialogue in which he observes and comments on his fellow citizens and the architecture that surrounds him in the street before being led by his nose to thinking about Italy and by his ears to Beatle-era England and his friends at the time.

Heidegger employs the term Ausserlichkeit (outwardness, externality) to describe the superficial appearances of routine actions and concerns, and "everydayness" to describe "the pallid lack of mood that dominates the "grey everyday' through and through" (1962: 395). Heidegger is not assigning a negative character to everyday life but arguing that people's interactions with familiar objects and places are always accompanied by a 
specific state of mind. However, the 100 inner dialogues that were collected for New York Stories, suggests Heidegger mistakenly conflates the exterior expression of ordinary, everyday activities with ascribing content to people's lived, experiential interior. By making inferences and assertions based on outward appearances, people's ongoing activities are accorded a pallid lack of mood rather than the complexity and diversity of emotions, feelings, and dilemmas that constitute the underlying thoughtscape of social life. perceptions and experiences based upon the observation of daily practice and other forms of extrinsic expression that are present to the eye and ear and make social life open to anthropological observation and theorisation. The problem of perception, subjectivity and how to read and understand people's observable or audible actions remains one of the most enduring epistemological and methodological problems encountered by anthropologists in the field. From Evans-Pritchard's declaration that individual perceptions have 'no wider collective validity' and the 'subject bristles with difficulties' (1969: 107), through Geertz's (1973) long-standing commitment to external, publicly observable symbols as the primary realm of anthropological study, to Bourdieu's dismissal of interest in lived experience as a complacent form of 'flabby humanism' (1990: 5), the potential problem with making anthropological claims about people's interior dialogues and imaginative lifeworlds means they remain unrepresented within many ethnographic accounts.

41 The lack of ethnographic attention to inner speech and expression is perhaps unsurprising given its transitory and sometimes ungraspable character, as well as its potential to invalidate anthropological truth claims concerning people's intentions, actions and moral worldviews. At times, the constitution and character of people's inner expressions might even be diametrically opposed to their public expressions-an experience no doubt familiar to many anthropologists in the field and their own social lives-thereby threatening to undermine the evidential grounds for making claims based upon the observation and interpretation of extrinsic forms. The resulting epistemological privilege frequently granted to the exterior within contemporary philosophy and social science (Johnson 1999) has allowed social theorists to claim knowledge about people's lived experiences and worldviews through the erroneous, yet epistemologically convenient, practice of inferring people's experiences and worldviews from the surrounding social context or via the postulation of abstract theoretical or social structures, rather than providing empirical evidence about the content and possibly oppositional character of people's private expressions. However, as Jackson (1996) has pointed out, anthropological theory and explanation are not determining agents and it is a mistake to confuse the metaphorical abstractions used to theorise and analyse people's lives and actions with the reality of their lived experiences. Indeed, I would argue it is virtually impossible to offer an empirically reliable and grounded account of people's perception, experience and understanding of the world without accounting for the diverse combinations of inner speech, intentionality and emotion that mediate people's social lives or from theoretical or contextual analysis alone.

42 For anthropology, this might be as much a question of disciplinary authority and epistemological convenience, as it is puppetry and ventriloquism (Appadurai 1988). In response a practice-based ethnographic approach to people's internal expressive activities not only provides empirical insights into social life, experience and the human 
condition but generates data for analysis that helps ensure the debate about interiority is not conducted at levels of theoretical generalisation and assertion and has the potential to generate more realistic ethnographies and representations of social life in which anthropological subjects can recognise the qualities of their own subjectivity and lived experience.

By bringing an anthropological focus to the field of inner expression, my aim here has thus been to offer a critical rethinking of the ontological and evidential status accorded to people's experiential interior within the social sciences and open up the debate about the role (or otherwise) of interiority across different social and cultural contexts, as well as develop new practical ways of researching how people's inner lifeworlds might relate to extrinsic, audible and observable expressions, principally in relation to interior dialogue and urban experience but also in terms of understanding social life more generally. Although, the material presented here, cannot provide anything more than a partial and flawed instance of people's inner dialogues and the thoughtscape of New York, rather than avoiding or simply disregarding people's thoughts and perceptions or subjecting them to ungrounded theoretical speculation and assertion, it nevertheless allows us to take the practices of inner speech and imagery that brain scientists argue are fundamental to human life-but do not ascribe ethnographic content to-and show the process at work within a practical fieldwork context whereby the content emerges in 'real time' in the moment and location of its original articulation.

\section{BIBLIOGRAPHY}

\section{Books and articles}

Appadurai, A. 1988. Introduction: Place and voice in anthropological theory. Cultural Anthropology 3.1: 16-20.

Bateson, G. 1972. Steps to an ecology of mind: Collected essays in Anthropology, Psychiatry, Evolution, and Epistemology. Chicago: University of Chicago Press.

Bourdieu, P. 1990. In other words: Essays toward a Reflexive Sociology. Stanford: Stanford University Press.

Carruthers, P. 2002. The cognitive functions of language. Behavioural and Brain Sciences 25: 657726.

Crapanzano, V. 2004. Imaginative horizons: An essay in Literary-Philosophical Anthropology.

Chicago:University of Chicago Press.

Evans-Pritchard, E. 1969. The Nuer. Oxford: Clarendon.

Fernyhough, C 2013. The voices within: The power of talking to yourself. New Scientist, June 3, number 2919.

Geertz, C. 1973. Interpretation of cultures: New York: Basic Books.

Heidegger, M. 1962. Being and time. Oxford Blackwell. 
Hurlburt, R. 2009 Descriptive experience sampling. In Oxford companion to consciousness, T. Baynes, A. Cleermans \& P Wilken, eds. Pp. 225-227. Oxford: Oxford University Press.

Irving, A. 2005. Life made strange: An essay on the reinhabitation of bodies and landscapes. In Qualities of Time, W. James, D. Mills, eds. Pp. 317-331. Oxford and New York: Berg.

Irving, A. 2007 Ethnography, art and death" Journal of the Royal Anthropological Institute n.s.13(1), pages $185-208$

Irving, A. 2009 The color of pain. Public Culture. 21: 2. 293-319.

Irving, A. 2010. Dangerous substances and visible evidence: Tears, blood, alcohol, pills. Visual Studies 25.1: 24-35.

Irving, A. 2011. Strange distance: Towards an anthropology of interior dialogue. Medical Anthropology Quarterly. 25:1.

Irving, A. 2013. Into the gloaming: A montage of the senses. In Transcultural Montage. R. Willerslev and C. Suhr, eds. Pp.76-96. Oxford and New York: Berghahn Books.

Irving, A. 2016. The art of life and death: Radical aesthetics and ethnographic practice. HAU Malinowski Monograph Series. Chicago: University of Chicago Press.

Jackson, M. 1996. Phenomenology, radical empiricism, and anthropological critique. In Things as They Are: New Directions in Phenomenological Anthropology, M. Jackson ed. Pp. 1-43. Bloomington: Indiana University Press.

James, W. 1890. Principles of psychology (Vol. 1). New York: Holt.

James, W. 2000. Pragmatism and other writings. London: Penguin.

Johnson, G. 1999. Inside and outside: Ontological considerations. In Merleau-Ponty, Interiority and exteriority, psychic life and the world. D. Olkowski and J. Morley, eds. Pp. 25-35. New York: SUNY Press.

Marx, K. 1988. The economic and philosophical manuscripts of 1844. Amherst, NY: Prometheus Books.

Walser, R. 1992. The walk and other stories. London: Serpent's Tail.

Ward, J. 2006. The student's guide to cognitive neuroscience. Hove and New York: Psychology Press.

Films

Irving, A. 2013. (dir). New York Stories: The Lives of Other Citizens. Granada Centre.

Steel, E. 2006. (dir.). The Bridge. Koch Lorber Films.

\section{NOTES}

1. Walking Fieldwork consisted of accompanying people as they carried out their everyday activities and asking them to narrate out loud the stream of their thoughts, emotions and experiences as they emerged in real time in order to grasp the phenomenology of the body-inaction, including the experience of living with bodily uncertainty. By listening to and recording people's spontaneous comments and narratives as they walked in their neighbourhoods, carried out daily chores and interacted with familiar objects and places, my correspondents offered glimpses into the 'real-time' streams of thought, mood and emotion that comprised their everyday life and experience but which were not usually publicly expressed. In doing so, 
movement and narrative were used to understand the phenomenology of the unwell body-inaction by crafting an ethnographic context for the narration of experiences, which are already lived in a person's daily life but otherwise might not be articulated or made public. For more general accounts of how experiences of terminal illness, death and dying are mediated by complex streams of interior dialogue and imagination, see Irving (2016).

\section{ABSTRACTS}

The capacity for a complex inner lifeworld that encompasses ongoing streams of inner dialogue and reverie, as well as non-linguistic or image based forms of thought, is an essential component of being human and central to many everyday actions and practices. Simply put, without inner expression there would be no self-understanding or social existence in any recognisable form. Despite this, it is largely a terra incognita for anthropology or is seen as irrelevant or intangible, rather than an empirical phenomenon that is directly constitutive of people's lived experiences and actions and therefore worthy of investigation. As such anthropology is at risk of only telling half the story of human life.

This presents a deep-seated problem for disciplines like anthropology that are based on empirical evidence insofar as it is primarily a methodological and practical problem rather than a conceptual one, especially with regard to how to research and represent the transient, streamlike and ever-changing character of people's interior expressions and experiences as they emerge in the moment. In response, this article attempts to offer an ethnographically grounded account of how people's lived experiences of the city are mediated by complex amalgams of inner expression, memory and imagination that largely remain beneath the surface of their public activities.

The accompanying video and sound recordings derive from an experimental practice-based research project, New York Stories, for which I recorded more than a hundred interior dialogues of random strangers as they moved around the city. The reader is invited to download sounds clips onto their phone or MP3 player and walk around their own city with someone else's thoughts in their head.

La capacité d'accéder à un mode de vie intérieure complexe, incluant des flots incessants de dialogues intérieurs ainsi qu'à des modes de pensées ni verbales ni visuelles, est une composante essentielle de l'être humain. Ce phénomène est central dans le cadre de nombreuses activités et pratiques. Clairement, sans expression intime il n'y a pas d'auto-compréhension ou d'existence sociale sous aucune forme reconnue.

Malgré cette situation, nous sommes face à une "terra incognita" en anthropologie, face à un phénomène perçu comme non-pertinent ou abstrait plutôt que comme un phénomène empirique qui constitue à part entière l' expérience de vie des gens et de leurs actions et mérite donc toute notre attention. Ainsi, l'anthropologie prend le risque de ne rendre compte que de la moitié de la vie.

Cela représente en fait, un problème de fond pour les disciplines comme l'anthropologie, organisées autour d'évidences empiriques. Cette situation relève d'un problème méthodologique et pratique plutôt que d'un problème conceptuel. Cette question est cruciale spécialement dans le cadre des recherches et des représentations de l'éphémère, des expressions intérieures en constante évolution qui affluent dans l'instantanéité. 
Face à cette situation, cet article propose d'offrir un travail ethnographique fondé sur la manière dont les expériences de vies des gens en ville sont composées d'amalgames complexes d'expressions intérieures, de mémoires et d'imaginations, largement enfouies lors de leurs activités publiques.

Les vidéos et les sons qui accompagnent cet article sont issus d'un terrain de recherche " Histoires de New-York" durant lequel j'ai enregistré plus d'une centaine de dialogues intérieurs de passants étrangers qui se déplaçaient dans la ville. Le lecteur est invité à télécharger des extraits sonores sur leur téléphone ou leur lecteur MP3 et de marcher dans leur propre ville avec les réflexions d'une autre personne dans sa tête.

La capacidad para un complejo mundo vital interior que abarca permanentes flujos de diálogo interior y ensueño, así como formas de pensamiento no lingüísticas o basadas en imágenes, es un componente esencial del ser humano y central para muchas acciones y prácticas cotidianas. En pocas palabras, sin expresión interna no habría auto-entendimiento o existencia social en ninguna forma reconocible. A pesar de esto, es en gran parte una tierra incógnita para la antropología o se considera como algo irrelevante o intangible, más que como un fenómeno empírico que es directamente constitutivo de las experiencias y acciones vividas de las personas y por lo tanto digno de investigación. Por consiguiente, antropología corre el riesgo de rendir cuentas solamente de la mitad de la historia de la vida humana.

Esto plantea un problema profundamente arraigado para disciplinas como la antropología que se basan en evidencia empírica en la medida en que se trata principalmente de un problema metodológico y práctico, más que conceptual, especialmente en cuanto a cómo investigar y representar las expresiones internas de la gente (transitorias, fluidas y siempre cambiantes) a medida que van surgiendo. En respuesta, este artículo intenta ofrecer una explicación basada en una etnografía sobre cómo las experiencias vividas por la gente de la ciudad están mediadas por complejos amalgamas de expresión interna, memoria e imaginación que en gran medida permanecen bajo la superficie de sus actividades públicas.

Las grabaciones de video y sonido que se acompañan son el resultado de un proyecto de investigación experimental basado en la práctica, New York Stories, para el cual grabé más de cien diálogos interiores de individuos desconocidos elegidos al azar mientras paseaban por la ciudad. Se invita al lector a descargar clips de sonidos en su teléfono o reproductor de MP3 y caminar alrededor de su propia ciudad con los pensamientos de otra persona en la cabeza.

\section{INDEX}

Keywords: New York City, cognitive anthropology, inner dialogue, thoughtscape, experimental methods

Palabras claves: New York City, cognitive anthropology, inner dialogue, thoughtscape, experimental methods

Mots-clés: Ville de New York, anthropologie cognitive, dialogue intérieur, espace, methodes expériementales

\section{AUTHOR}

\section{ANDREW IRVING}

University of Manchester

andrew.irving@manchester.ac.uk 